\title{
Jurist-Diction
}

Volume 4 No. 2, Maret 2021

\section{Pertanggungjawaban Pidana Pencemaran Nama Baik Melalui Media Sosial}

\author{
Firman Satrio Hutomo \\ firman_025@yahoo.com \\ Universitas Airlangga
}

\begin{tabular}{l} 
How to cite: \\
Firman Satrio \\
Hutomo'Pertanggungjawaban \\
Pidana Pencemaran Nama Baik \\
Melalui Media Sosial' (2021) \\
Vol. 4 No. 2 Jurist-Diction. \\
Histori artikel: \\
Submit 16 Januari 2021; \\
Diterima 1 Februari 2021; \\
Diterbitkan 1 Maret 2021. \\
DOI: \\
10.20473/jd.v4i2.25783 \\
p-ISSN: 2721-8392 \\
e-ISSN: 2655-8297 \\
\hline cC) (1) (2) (2)
\end{tabular}

How to cite:

Firman Satrio

Pidana Pencemaran Nama Baik

Melalui Media Sosial' (2021)

Histori artikel:

Diterima 1 Februari 2021,

p-ISSN: 2721-8392

\section{Abstract}

This study aims to find out the rules about criminalization and insulting through social media in Indonesia's criminal law and enforcement in an insulting thing through social media. This is a normative law study, perspective by using legal material as a source, premier law and/or even the secondary ones. Approaching method that used in the study is the law and case approach. Based on the study result and discussion, it finds out that the legal construction and effectivity of liability for the preparator of defamation through social media has been regulated on article 27 paragraph (3) No. 112008 statute about the Information and Electronic Transactions. In the criminal code, defamations are regulated in Article 310 paragraph (1) of the criminal code. For the second conclusion is that the actions in some of the decisions above where the defendant uploaded on a Facebook account showed a motive or intention to insult and / or defame the preparators. And thus, the act fulfils the criminal element in Article 45 paragraph (3) of the ITE Law.

Keywords: Land Procurement; Sale and Purchase Resistant of Land; Land Conflict; Ownership.

\section{Abstrak}

Penelitian ini bertujuan untuk mengetahui pengaturan mengenai pemidanaan dan delik penghinaan melalui media sosial di dalam sistem hukum pidana Indonesia dan penegakan hukum dalam perkara penghinaan melalui media social. Penelitian ini merupakan penelitian hukum normatif, bersifat preskriptif dengan menggunakan sumber bahan hukum, baik bahan hukum primer maupun bahan hukum sekunder. Pendekatan ini yang digunakan adalah pendekatan undang-undang dan pendekatan kasus. Hasil penelitian yakni pertama, konstruksi hukum dan efektifitas pertanggungjawaban bagi pelaku tindak pidana penceamran namabaik melalui media social telah diatur dalam pasal 27 ayat (3) Undang-undang nomor 11 Tahun 2008 tentang Informasi dan Transaksi Elektronik jo Pasal 45 ayat (3) Undang-undang Nomor 19 Tahun 2016 tentang Informasi dan Transaksi Elektronik. Di dalam KUHP tindak pidana pencemaran nama baik diatur dalam Pasal 310 ayat (1) KUHP. Kedua bahwa perbuatan pada beberapa putusan diatas dimana terdakwa mengupload pada akun facebook yang menunjukkan adanya motif atau niat untuk melakukan penghinaan dan/atau pencemaran nama baik terhadap pelaku. Dan dengan demikian perbuatan tersebut memenuhi unsur pidana dalam Pasal 45 ayat (3) UU ITE.

Kata Kunci: Delik; Penghinaan; Media Sosial; Sistem Pemidanaan. 


\section{Pendahuluan}

Salah satu bentuk tindak pidana yang dalam pelaksanaanya semakin mutakhir untuk dilakukan dengan menggunakan internet di Indonesia adalah tindak pidana penghinaan atau pencemaran nama baik yang dilakukan oleh individu terhadap individu maupun kelompok yang lain. Tindak pidana penghinaan (beleediging) adalah penyerangan terhadap martabat kehormatan dan nama baik bersifat pribadi maupun komunal yang menimbulkan perasaan malu, ketersinggungan, tercemar atau terhina, melahirkan rasa tidak senang, kebencian, tidak puas, sakit hati, amarah, dan penderitaan yang menyiksa batin orang lain. ${ }^{1}$

Hal-hal yang dikomunikasikan atau dipublikasikan melalui internet adalah merupakan tindak pidana penghinaan atau pencemaran nama baik apabila hal tersebut adalah tidak benar adanya bagi pihak korban, baik itu merupakan yang merusak reputasi ataupun yang membawa kerugian material bagi pihak korban. Publikasi atau komunikasi tentang diri pihak lain dapat dikatakan pencemaran nama baik atau penghinaan, baik dilakukan dengan kata-kata atau tulisan yang terang-terangan maupun bentuk yang tersembunyi namun mengandung konotasi yang merusak reputasi seseorang atau badan atau instansi tertentu.

Pada mulanya kejahatan dan pencemaran nama baik yang terjadi di Indonesia hanya dikenakan peraturan yang diatur dalam Kitab Undang-Undang Hukum Pidana yang selanjutnya disebut KUHP. Setelah pergeseran zaman di era digital ini maka pemerintah khususnya aparat penegak hukum terdorong untuk memberikan pengaturan terkait tindak pidana cybercrime yang kemudian disebut cyberlaw dengan menetapkan Undang-Undang Nomor. 19 Tahun 2016 Tentang perubahan atas Undang-Undang Nomor. 11 Tahun 2008 Tentang Informasi dan Transaksi Elektronik.

Kejahatan penghinaan dapat dibedakan menjadi penghinaan umum (diatur dalam bab XVI buku II) dan penghinaan khusus (tersebar di luar bab XVI buku II). Objek penghinaan umum adalah berupa rasa harga diri atau martabat mengenai

\footnotetext{
1 Adami Chazawi, Hukum Pidana Positif penghinaan (Edisi Revisi) (Media Nusantara Creative 2016).[1].
} 
kehormatan dan mengenai nama baik orang pribadi (bersifat pribadi). Sebaliknya penghinaan khusus, objek penghinaan adalah rasa/perasaan harga diri atau martabat mengenai kehormatan dan nama baik bersifat komunal atau kelompok. ${ }^{2}$

Kejahatan yang oleh Undang-undang diberi kualifikasi pencemaran atau penistaan (smaad) dan pencemaran tertulis (smaadschrijft) dirumuskan selengkapnya di dalam Pasal 310, pengertian hukum tentang kualifikasi pencemaran dirumuskan pada ayat (1), yang sesugguhnya pencemaran lisan (walaupun perkataan lisan tidak disebutkan), kebalikan dari pencemaran dalam ayat (2). Pada ayat (2) dirumuskan pengertian tentang pencemaran tertulis, sedangkan pada ayat (3) mencantumkan tentang pengecualian pemidanaan pencemaran dan pencemaran tertulis pada ayat (1) dan (2). Merupakan dasar hapusnya sifat melawan hukum pencemaran. Dapat juga disebut alasan penghapusan pidana khusus pada pencemaran dan pencemaran tertulis. ${ }^{3}$ Dalam Undang-Undang Nomor 32 Tahun 2002 tentang Penyiaran, delik pencemaran nama baik terdapat dalam Pasal 36 ayat (5), yaitu:

(a) bersifat fitnah, menghasut, menyesatkan dan/atau bohong;

(b) menonjolkan unsur kekerasan, cabul, perjudian, penyalahgunaan narkotika dan obat terlarang;

(c) mempertentangkan suku, agama, ras, dan atargolongan. ${ }^{4}$

Sedangkan dalam Undang - Undang Nomor 19 Tahun 2016 entang Perubahan Atas Undang - Undang Nomor 11 Tahun 2008 tentang Informasi dan Transaksi Elektronik, delik pencemaran nama baik terdapat dalam Pasal 45 Ayat (3), yaitu:

"Setiap Orang yang dengan sengaja dan tanpa hak mendistribusikan dan/atau mentransmisikan dan/atau membuat dapat diaksesnya informasi Elektronik dan/atau Dokumen Elektronik yang memiliki muatan penghinaan dan/atau pencemaran nama baik sebagaimana dimaksud dalam pasal 27 ayat (3) dipidana dengan pidana penjara paling lama 4 (empat) tahun dan/atau denda paling banyak Rp.750.000.000,00 (tujuh ratus lima puluh juta rupiah)”.

Dengan adanya Undang - Undang Nomor 19 Tahun 2016 tentang Perubahan Atas Undang - Undang Nomor 11 Tahun 2008 tentang Infornasi dan Transaksi Elektronik

\footnotetext{
2 Adami.Chazawi, Hukum Pidana Positif Penghinaan (PMN Surabaya 2009).[87].

3 ibid.

4 ibid.
} 
maka aturan mengenai informasi elektronik telah mendapatkan payung hukum. Kejahatan dunia maya (Cyber Crime) juga dapat lebih mudah untuk diproses secara hukum karena informasi elektronik, dokumen elektronik dan hasil cetakannya merupakan alat bukti hukum yang sah, sehingga pembuktian dalam kasus - kasus cybercrime menjadi lebih mudah. ${ }^{5}$

Berkaitan dengan kasus tindak pidana pencemaran nama baik melalui media sosial facebook, akan dianalisis yang terjadi di Desa Pandahan Kecamatan Bati Bati, Kabupaten Tanah Laut, Propinsi Kalimantan Selatan. Pencemaran nama baik melalui media sosial tersebut dilakukan oleh H.Ramlan alias Alan Bin H.Hamzah atas dasar untuk menagih hutang.

Dari tindakan tersebut jika dilihat secara teoritik dalam hukum pidana maka terdapat unsur kesengajaan dalam tindak pidana tersebut. Dapat diketahui dari ringkasan cerita diatas bahwa pencemaran nama baik melalui media sosial facebook oleh H.Ramlan dilakukan dengan sengaja memilik muatan penghinaan dan pencemaran nama baik. Penelitian ini bertujuan untuk mengetahui bagaimana penerapan hukum pidana materiil berdasarkan Undang-Undang Nomor 19 Tahun 2016 Perubahan Atas Undang-Undang Nomor 11 Tahun 2008 Tentang Informasi dan Transaksi Elektronik dalam putusan Nomor 352/Pid.B/2017/PN Pli.

\section{Konsep Tindak Pidana Pencemaran Nama Baik}

Pengertian tentang tindak pidana dalam Kitab Undang-Undang Hukum Pidana (KUHP) dikenal dengan istilah (strafbaarfeit) dan dalam kepustakaan tentang hukum pidana sering mempergunakan istilah delik, sedanagkan pembuat undang-undang merumuskan suatu undang-undang mempergunakan istilah peristiwa pidana atau perbuatan pidana atau tindak pidana. ${ }^{6}$ Para pakar asing hukum pidana menggunakan istilah tindak pidana atau perbuatan pidana atau peristiwa pidana dengan istilah: ${ }^{7}$

\footnotetext{
5 ibid.

6 Amir Ilyas, 'Memahami Tindak Pidana Dan Pertanggungjawaban Pidana Sebagai Syarat Pemidanaan’ (Rangkang Education Yogyakarta \& PuKAP-Indonesia 2012).[18].

7 ibid.
} 
1. Strafbaarfeit adalah peristiwa pidana;

2. Strafbare Handlung diterjemahkan dengan perbuatan pidana, yang digunakan oleh para sarjana hukum pidana;

3. Criminal Act diterjemahkan dengan istilah perbuatan kriminal.

Seperti yang diungkapkan oleh seorang ahli hukum pidana yaitu Molejatno yang berpendapat bahwa pengertian tindak pidana yang menurut istilah beliau yakni perbuatan pidana adalah perbuatan yang melanggar yang dilanggar oleh suatu aturan hukum, larangan mana disertai ancaman (sanksi) yang berupa pidana tertentu bagi siapa saja yang melanggar larangan tersebut. ${ }^{8}$ Adapun didalam perumusan tersebut yang mengandung kalimat aturan hukum pidana dimaksudkan akan memenuhi keadaan hukum di Indonesia yang masih mengenal kehidupan hukum yang tertulis maupun hukum yang tidak tertulis.

Klasifikasi tindak pidana menurut sistem Kitab Undang - undang Hukum Pidana (KUHP) dibagi menjadi dua bagian, kejahatan (minsdrijven) yang diatur dalam Buku II KUHP dan pelanggaran (overtredigen) yang diatur dalam Buku III KUHP. Pembagian perbedaan kejahatan dan pelanggaran didasarkan atas perbedaan prinsipil.

Pengertian mengenai kehormatan, menurut Satochid kartanegara adalah harga diri atau martabat manusia yang disandarkan pada tata susila. ${ }^{9}$ Kehormatan dapat diberikan batasan, adalah harga diri atau harkat dan martabat yang dimiliki oleh orang yang disandarkan pada tata atau nilai-nilai (adab) kesopanan dalam pergaulan amsyarakat. Arti tata adalah nilai-nilai yang baik (adab) yang hidup serta dijunjung tinggi dan dipertahankan oleh masyarakat. adab kesopanan adalah adab sopan santun yang baik dalam pergaulan hidup bermasyarakat, yang dipertahankan dan dijunjung tinggi oleh semua anggota masyarakat. ${ }^{10}$

Sedangkan nama baik adalah suatu rasa harga diri atau martabat yang didasarkan pada pandangan atau penilaian yang baik oleh masyarakat terhadap sesseorang dalam pergaulan bermasayarakat. Nama baik disini adalah rasa atau

\footnotetext{
8 Moeljatno, Asas-Asas Hukum Pidana (PT.Bina Aksara 1982). [55].

9 Satochid Kartanegara, Hukum Pidana II Delik-Delik Tertentu.[111].

${ }^{10}$ Adami Chazawi, Hukum Pidana Positif Penghinaan (CV. Putra Media Nusantara 2009).[7].
} 
perasaan seseorang mengenai dirinya yang dipandang atau dinilai orang-orang lain sebagai baik, walaupun mungkin ada banyak orang yang pada kenyataannya tidak memandang sebagai orang yang baik. Bagi bangsa Indonesia, pasal pencemaran nama baik dianggap sesuai dengan karakter bangsa ini yang menjunjung tinggi adat dan budaya timur, pencemaran nama baik dianggap melanggar norma sopan santun bahkan bisa melanggar norma agama jika yang dituduhkan mengandung unsur fitnah. Berdasarkan hal tersebut, pencemaran nama baik pada dasarnya merupakan tindakan yang sudah dianggap sebagai bentuk ketidakadilan sebelum dinyatakan dalam undang - undang karena telah melanggar kaidah sopan santun. Bahkan lebih dari itu, penghinaan dan pencemaran nama baik dianggap melanggar norma agama jika dalam substansi pencemaran itu terdapat fitnah. ${ }^{11}$

Istilah delik pencemaran nama baik di indonesia bukan merupakan juridical term (istilah hukum) karena tidak secara eksplisit disebutkan dalam Kitab Undang -Undang Hukum Pidana (KUHP), namun merupakan istilah yang berkembang didunia akademik (academic term) dan masyarakat sosial (social term). Istilah hukum yang dipakai di Indonesia nampaknya belum jelas dalam membedakan antara pencemaran nama baik dan penghinaan, hal ini bisa dilihat dalam ketentuan KUHP dan peraturan perundang-undangan di luar KUHP. Hal ini menyebabkan multitafsir dalam pelaksanaannya sehingga melanggar hak asasi manusia.

Tindak pidana pencemaran nama baik yang menjadi obyek yang diserang adalah kehormatan seseorang dengan tuduhan mengenai suatu berita kebohongan yang mengakibatkan jatuhnya kehormatan seseorang. Perbuatan menyampaikan berita tidak sesuai dengan fakta atau berita bohong dalam peraturan yang diatur dalam KUHP. Perbuatan menyampaikan suatu berita yang seolah-olah berita tersebut dibuat benar padahal suatu kebohongan yang sengaja dipalsukan yang bertujuan untuk menjatuhkan harga diri seseorang merupakan suatu tindak pidana pencemaran nama baik. Pencemaran nama baik berbeda dengan sesuatu pernyataan yang berupa opini ataupun pendapat, kedua hal tersebut tidak termasuk objek

11 Asrianto Zainal, 'Pencemaran Nama Baik Melalui Teknologi Informasi Ditinjau Dari Hukum Pidana’ (2016) 9 Fakultas Syariah IAIN Kediri.[62]. 
Tindak Pidana Pencemaran Nama Baik karena opini dan pendapat yang tidak memiliki tujuan dengan sengaja menjatuhkan harga diri seseorang. Opini tersebut tidak termasuk dalam pencemaran nama baik karena opini dilindungi oleh asas kebebasan berpendapat. Di Indonesia opini dijamin dalam Undang - Undang Dasar Negara Republik Indonesia pasal 28 F, karena itu yang dilarang oleh hukum adalah memalsukan fakta agar seseorang tercemar nama baiknya.

\section{Konsep Tindak Pidana Pencemaran Nama Baik Dalam KUHP}

Kejahatan yang oleh undang-undang diberi kualifikasi pencemaran atau penistaan (smaad) dan pencemaran tertulis (smaadschrift) dirumuskan selengkapnya di dalam 310 KUHP. Bila rumusan kejahatan pencemaran pada pasal 310 ayat (1), maka terdiri dari unsur objektif dan unsur subyektif. Unsur objektif yang pertama adalah perbuatannya, dimana perbuatan tersebut menyerang, yang kedua yaitu objeknya dimana objeknya adalah kehormatan orang dan nama baik, sedangkan yang ketiga adalah caranya dengan menuduhkan perbuatan tertentu. Apabila unsur subjektifnya adalah kesalahan yang disengaja dan maksudnya terang agar diketahui secara umum.

Perbuatan menyerang (aanranden) tidaklah bersifat fisik, karena terhadap apa yang diserang (objeknya) memang bukan fisik akan tetapi perasaan mengenai kehormatan dan perasaan mengenai nama baik orang. Arti penyerangan disini adalah menyampaikan ucapan dengan cara menuduhkan melakukan perbuatan tertentu, dan penyerangan tersebut ditujukan pada kehormatan dan nama baik orang yang mengakibatkan rasa harga diri atau martabat orang itu dicemarkan, dipermalukan ataupun direndahkan.

Objek yang diserang adalah rasa atau perasaan harga diri mengenai kehormatan, dan rasa atau perasaan harga diri mengenai nama baik orang. rasa harga diri dalam penghinaan adalah rasa harga diri di bidang kehormatan, dan rasa harga diri di bidang nama baik. Rasa harga diri dibidang kehormatan berbeda dengan rasa harga diri di bidang nama baik meskipun dalam keduanya terdapat sifat yang sama. persamaan keduanya terletak pada akibat dari penyerangan. Baik penyerangan 
terhadap kehormatan maupun nama baik, kedua-duanya menimbulkan perasaan turun atau jatuhnya atau tercemarnya rasa harga diriatau martabat seseorang yang mejadikan orang tersebut terhina dan malu.

Objek penceamran kedua yaitu rasa harga diri orang mengenai nama baik. Adalah suatu rasa harga diri atau martabat yang didasarkan pada pandangan atau penilaian yang baik dari masyarakat terhadap seseorang dalam hubungan hidup bermasyarakat. Rasa harga diri mengenai nama baik tumbuh dan berada dalam batin seseorang berkat adanya interaksi sosial antara pribadi yang bersangkutan dengan sesama komunitas sosial. Nama baik ini diakui oleh masyarakat, bagi seseorang dia memiliki rasa atau perasaan bahwa masyarakat memberikan pengakuan tentang segala sesuatu yang baik. Jadi nama baik adalah rasa atau perasaan seseorang mengenai dirinya bahwa dirinya dipandang oleh orang-orang lain sebagai baik.

Kejahatan pencemaran terdapat dua unsur kesalahan, yakni sengaja (opzettelijk) dan maksud atau tujuan. Walaupun dalam doktrin, maksud itu adalah juga kesengajaan (dalam arti sempit), yang disebut dengan kesengajaan sebagai maksud. Tetapi, fungsi unsur sengaja dan unsur maksud dalam pencemaran berbdeda. Sikap batin sengaja ditujukan pada perbuatan menyerang kehormatan atau nama baik orang (perbuatan dan objek perbuatan). Sementara sikap batin maksud ditunjukan pada unsur diketahui oleh umum mengenai perbuatan apa yang dituduhkan pada orang itu, maka unsur yang diliputi oleh sengaja dalah unsur-unsur berikut: ${ }^{12}$

1. Perbuatan menyerang;

2. Objek; kehormatan atau nama baik orang;

3. Dengan menuduh suatu perbuatan tertentu.

Dalam kejahatan pencemaran tertulis yang dipersalahkan sebagai pembuat (dader) hanyalah orang yang menyiarkan, yang mempertunjukan dan yang menempelkan, dan tidak bagi orang yang membuat tulisan dan yang membuat gambar. ${ }^{13}$ Apabila tulisan atau gambar yang berisi mencemarkan orang dibuat oleh

12 Jupri,'Delik Penghinaan',(2011),< https://www.negarahukum.com/hukum/delik-penghinaan.html $>$, dikunjungi pada tanggal 25 Januari 2020.

13 ibid. 
orang lain selain yang menyiarkan ataupun yang menempelkan, dan dengan hanya sekedar menolong orang lain yang akan menyiarkan, yang akan menempelkan atau yang akan menyebarkan, maka si pembuat tulisan atau gambar ini dapat dikatakan sebagai pembuat pembantu. Akan tetapi apabila orang si pembuat tulisan atau gambar memiliki sikap batin yang sama dengan orang yang menyiarkan, yang menempelkan atau yang mempertunjukkan sengaja menyerang kehormatan orangyang dimaksudkannya agar diketahui secara umum, maka si pembuat tulisan atau gambar tersebut tidak bisa dikatakan sebagai pembuat pembantu, akan tetapi pembuat peserta.

Menurut isi dari pasal 61 Ayat (1) dan Ayat (2) KUHP yaitu:

Ayat (1) "Mengenai kejahatan yang dilakukan dengan percetakan, penerbitnya selaku demikian tidak dituntut bila dalam barang cetakan disebutkan nama dan tempat tinggalnya, sedangkan perbuatannya sudah dikenal atau diberitahukan oleh penerbit pada waktu pertama kali ditegur setelah penuntutan dimulai agar memberitahukan nama si pembuat".

Ayat (2) "aturan ini tidak berlaku bila pelaku pada saat barang cetakan terbit tidak dapat dituntut atau sudah menetap di luar indonesia".

Kejahatan fitnah (laster) dirumuskan didalam pasal 311 KUHP, yang selengkapnya adalah:

Ayat (1) "jika yang melakukan kejahatan pencemaran atau pencemaran tertulis dibolehkan untuk membuktikan apa yang dituduhkan itu benar, tidak membuktikannya, dan tuduhan dilakukan bertentangan dengan apa yang diketahui, maka dia diancam melakukan fitnah dengan pidana penjara paling lama empat tahun".

Ayat (2) “pencabutan hak-hak berdasarkan pasal 35 No.1-3 dapat dijatuhkan”. Kejahatan fitnah bukanlah kejahatan yang berdiri sendiri, terlepas dari kejahatan pencemaran dan penceamaran tertulis melainkan merupakan bentuk khusus dari pencemaran. Karena untuk terjadinya fitnah diisyaratkan adanya pencemaran ataupun juga pencemaran tertulis. Bila rumusan pasal 311 ayat (1) diperinci, maka akan dapat dilihat unsur-unsur pencemaran atau pencemaran tertulis ada didalamnya, unsur-unsurnya selengkapnya sebagai berikut: ${ }^{14}$

1. Semua unsur (objektif dan subjektif) dari:

14 ibid. 

a. Pencemaran (Pasal 310 Ayat (1))
b. Pencemaran tertulis (Pasal 310 Ayat (2))

2. Si pembuat diperbolehkan untuk membuktikan apa yang dimudahkannya itu benar

a. Tetapi si pembuat tidak membuktikan kebenaran tuduhannya

b. Apa yang menjadi isi tuduhannya adalah bertentangan dengan yang diketahuinya.

c. Apabila si pembuat pencemaran menuduhkan perbuatan pada orang lain, perbuatan mana berupa tindak pidana, maka dalam hal demikian bisa terjadi terhadap si pembuat tindak pidana yang dituduh tadi dilakukan penyidikan dan penuntutan pidana di sidang pengadilan. Dalam hal ini berlakulah pasal 314 KUHP, ${ }^{15}$ yang merumuskan sebagai berikut:

d. Ayat (1) "jika yang dihina, dengan putusan hakim yang menjadi tetap, dinyatakan bersalah bersalah atas hal yang dituduhkan, maka pemidanaan karena fitnah tidak mungkin".

e. Ayat (2) "jika dengan putusan hakim yang telah menjadi tetap dibebaskan dari yang dituduhkan, maka putusan itu dipandang sebagai bukti sempurna bahwa hal yang dituduhkan tidak benar".

f. Ayat (3) "jika terhadap yang dihina telah dimulai penuntutan pidana karena hal yang dituduhkan padanya, maka penuntutan karena fitnah dihentikan sampai mendapat putusan yang menjadi tetap tentang hal yang menjadi tuduhan".

Pasal 314 KUHP ini adalah penegasan Undang-Undang dalam rangka untuk menjamin kepastian hukum, khususnya mengenai ketentuan Ayat (3). Sementara Ayat (1) dan (2) hanyalah berupa penegasan Undang-Undang belaka. ${ }^{16}$ Mengenai penjatuhan pidana fitnah (laster), yang ada kekhususannya ialah kepada si pembuat fitnah yang terbukti bersalah disamping dijatuhkan pidana sesuai dengan ancaman pada fitnah yaitu empat tahun penjara, dapat juga dijatuhkan pidana pencabutan hak-hak tertentu sebagaimana yang dirumuskan pada Pasal 35 No.1-2 yaitu berupa:

1. Hak memegang jabatan pada umumnya atau jabatan tertentu, dan Hak memasuki angkatan bersenjata.

2. Bentuk penghinaan ringan atau penghinaan biasa diatur dalam pasal $315 \mathrm{KUHP}$ yang rumusannya sebagai berikut:

"Tiap-tiap penghinaan dengan sengaja yang tidak bersifat pencemaran
15 ibid.
16 ibid. 
atau pencemaran tertulis yang dilakukan terhadap seseorang, baik di muka umum dengan lisan atau tulisan, di muka orang itu sendiri dengan lisan atau perbuatan, atau dengan surat yang dikirimkan atau diterimakan kepadanya, diancam karena penghinaan ringan dengan pidana penjara paling lama empat bulan dua minggu atau pidana denda paling banyak empat ribu lima ratus rupiah".

Pengertiannya jika penghinaan (pencemaran nama baik) itu dilakukan dengan jalan menuduh seseorang telah melakukan suatu perbuatan, maka hal itu tergolong pasal 310 dan 311 KUHP. Namun apabila dengan jalan atau cara lain, seperti misalnya mengumpat atau memaki-maki dengan kata-kata keji yang menurut pendapat umum dapat digolongkan sebagai kata-kata penghinaan, maka hal ini tergolong memenuhi unsur pasal 315 KUHP yang disebut penghinaan ringan atau biasa. ${ }^{17}$ Dari ketentuan pasal 315 KUHP ini maka terdapat unsur-unsur objektif yaitu perbuatan dengan menyerang, objeknya adalah kehormatan orang dan nama baik orang, kemudian terdapat beberapa caranya:

a. Dengan lisan di muka umum;

b. Dengan tulisan di muka umum;

c. Dengan lisan di muka orang itu sendiri;

d. Dengan perbuatan di muka orang itu sendiri;

e. Dengan surat yang dikirimkan atau diterimakan kepadanya. ${ }^{18}$

Rumusan Pasal 317 KUHP memperlihatkan adanya kaitan yang erat antara delik pengaduan fitnah dengan delik pencemaran, dan pencemaran tertulis. Kaitan erat antara delik fitnah dengan delik pencemaran atau pencemaran tertulis, yaitu bahwa delik pengaduan fitnah merupakan ketentuan khusus terhadap delik pencemaran tertulis yang merupakan ketentuan umum. Dirumuskan dalam Pasal 317 KUHP yang selengkapnya sebagai berikut:

Ayat (1) barangsiapa dengan sengaja mengajukan pengaduan atau pemberitahuan palsu kepada penguasa, baik secara tertulis maupun untuk dituliskan, tentang seseorang sehingga kehormatan atau nama baiknya terserang, diancam karena melakukan pengaduan fitnah, dengan pidana penjara paling lama empat tahun.

Ayat (2) pencabutan hak-hak berdasarkan Pasal 35 No.1-3 dapat dijatuhkan.

${ }^{17}$ Reydi Vridell Awawangi, 'Pencemaran Nama Baik Dalam KUHP Dan Menurut UU No.11 Tahun 2008 Tentang Informasi Dan Transaksi Elektronik’ (2014) 3 Lex Crimen.[116].

${ }_{18}$ Ahmad Sofian Op.Cit.[123]. 
Unsur-unsur dari fitnah dengan pengaduan adalah dengan sengaja, menyampaikan laporan atau pengaduan tertulis palsu,disampaikan kepada penguasa, tentang orang tertentu, isinya menyerang kehormatan atau nama baik orang tersebut. ${ }^{19}$ Laporan atau pengaduan palsu tertulis maksudnya adalah bahwa yang disampaikan dengan lisan yang kemudian ditulis oleh penerima laporan atau pengaduan, laporan pengaduan yang disampaikan kepada pejabat negara. Laporan atau pengaduan itu mengenai orang tertentu tertentu pada umumnya penghinaan hanya dapat dilakukan terhadap manusia atau individu dalam arti punya nama, sehingga tidak dapat diperlakukan terhadap badan hukum meskipun badan hukum dapat memilki nama baik. ${ }^{20}$

\section{Konsep Pencemaran Nama Baik Melalui Media Sosial}

Kejahatan yang dilakukan dalam hal cyber crime timbul karena adanya pemanfaatan teknologi internet. Cyber crime dilakukan akibat adanya kecanggihan teknologi, komputer dan telekomunikasi untuk memperoleh keuntungan ataupun tidak, dengan merugikan pihak lain.

Hukum cyber atau cyber law, secara internasional digunakan untuk istilah hukum yang terkait dengan pemanfaatan teknologi informasi dan komunikasi, demikian pula hukum telematika yang merupakan perwujudan dari peningkatan digitalisasi, konten tipe yang berbeda (data, audio, video) diletakkan dalam suatu format yang sama dan dikirim terus melalui variasi teknologi komputer, handphone, televisi yang kemudian diteruskan pada platform yang berbeda. Perkembangan teknologi informasi telah menyebabkan dunia menjadi tidak memiliki batas dan menyebabkan perubahan sosial secara cepat. Sehingga dapat dikatakan teknologi informasi saat ini telah menjadi pedang bermata dua, karena selain memberikan kontribusi bagi peningkatan kesejahtraan, kemajuan, dan peradaban manusia, sekaligus menjadi sarana efektif perbuatan melawan hukum. ${ }^{21}$

\footnotetext{
${ }^{19}$ Leden Marpaung, Tindak Pidana Terhadap Kehormatan (PT.Sinar Grafika 2010).[37].

20 ibid.

${ }^{21}$ Ahmad Ramli, Cyber Law dan HAKI-Dalam System Hukum Indonesia (Rafika Aditama 2004).[1].
} 
Konsep aturan pencemaran nama baik melalui media elektronik atau media sosial dan perlindungan hukum bagi masyarakat terhadap adanya potensi pencemaran nama baik. Pencemaran nama baik melalui media sosial ataupun media elektronik lainnya merupakan perbuatan pencemaran nama baik yang telah diatur dalam KUHP Pasal 310 Ayat (1) namun dilakukan dengan menggunakan media elektronik atau media masa diatur dalam Pasal 27 Ayat (3) Undang-Undang Nomor 11 Tahun 2008 Tentang Informasi dan Transaksi Elektronik, sehingga kedua ketentuan tersebut satu sama lain tidak dapat dipisahkan. Dari kedua ketentutan tersebut unsur pidana yang kemudian dijadikan dasar untuk mengklasifikasi apakah perkara pencemaran nama baik yang terjadi termasuk pencemaran nama baik biasa atau pencemaran nama baik yang dilakukan melalui media sosial atau media elekronik, dan juga ada beberapa faktor-faktor yang mempengaruhi cyber crime diantaranya yaitu faktor politik, faktor ekonomi, dan faktor sosial budaya.

Adapun keterkaitan antara tindak pidana pencemaran nama baik melalui media sosial berdasarkan Pasal 27 Ayat (3) Undang -Undang Nomor 11 Tahun 2008 Tentang Informasi dan Transaksi Elektronik dengan kebebasan berpendapat. Bahwa kebebasan berpendapat merupakan hak setiap individu yang dijamin oleh konstitusi dan negara, maka dari itu Negara Republik Indonesia sebagai negara hukum dan demokratis berwenang dalam mengatur dan melindungi pelaksanaannya. Kebebasan berpendapat tanpa adanya sauatu tekanan dari pihak manapun maupun kebebasan berpikir telah diatur dalam Undang-Undang Dasar Republik Indonesia Tahun 1945 pasal 28 E Ayat (3), dimana setiap orang berhak atas kebebasan berserikat, berkumpul, dan mengutarakan pendapatnya. Kehadiran hak asasi manusia sebenarnya tidak diberikan oleh negara, melainkan asasi manusia menurut hipotesis John Locke merupakan hak-hak individu yang sifatnya kodrati, dimiliki setiap insan sejak lahir. ${ }^{22}$ Kebebasan berekspresi pada saat ini tidak hanya dapat ditunagkan melalui lisan maupun tulisan akan tetapi juga dapat dituangkan atau disampaikan melalui media sosial. Pemanfaatan teknologi

${ }^{22}$ El Muhtaj Majda, Hak Asasi dalam Konstitusi Indonesia (Kencanai 2007).[29]. 
informasi, media dan komunikasi secara tidak langsung telah mengubah baik perilaku masyarakat ataupun kehidupan dalam bersosialisasi yang menyebabkan dunia menjadi tanpa batas.

Meskipun kita memiliki hak kebebasan dalam mengeluarkan pendapat ataupun pikiran, akan tetapi kebebasan tersebut bukan meripakan mutlak yang tanpa batas, melainkan kebebasan yang bertanggung jawab. Karena kebebasan kita juga dibatasi akan kebebasan orang lain, nilai-nilai serta norma yang berlaku dalam hidup bermasyarakat, berbangsa dan bernegara. Batasan terhadap hak dan kebebasan menyampaikan pendapat dan pikiran khususnya di media sosial juga harus tetap pada jalur yang benar dalam tujuan menyampaikan informasi yang sebenarnya untuk kepentingan bersama. Undang-undang akan menjadi koridor pembatas saja supaya kebebasan mengeluarkan pendapat ataupun pikiran yang diperjuangkan tidak kebablasan. UU ITE menjadi salah satu batasan dalam tindak kejahatan melalui dunia maya.

\section{Analisis Putusan Mahkamah Konstitusi Tentang Pencemaran Nama Baik Melalui Media Sosial}

Pada putusan Mahkamah Konsitusi Nomor 2/PUU-VII/2009 terdapat alasanalasan permohonan mengajukan pengujian Undang-Undang bahwa pasal 27 ayat (3) UU Nomor 11 Tahun 2008 tentang Informasi dan Transaksi Elektronik telah bertentangan dengan UUD 1945, yakni pasal 1 ayat (2), Pasal 1 ayat (3), Pasal 27 ayat (1), Pasal 28, Pasal 28C ayat (1) dan ayat (2), Pasal 28D ayat (1), Pasal 28E ayat (2) dan ayat (3), Pasal 28F dan Pasal 28G ayat (1) UUD 1945. Bahwa menurut pemohon Pasal 27 ayat (3) UU ITE bertentangan dengan prinsip-prinsip negara hukum. Negara hukum didasarkan pada suatu keinginan bahwa kekuasaan negara harus dijalankan atas dasar hukum yang baik dan adil. Dalam negara hukum salah satu pilar yang sangat penting adalah perlindungan dan penghormatan terhadap hakhak asasi manusia. perlindungan terhadap HAM tersebut dimasyarakatkan secara luas dalam rangka mempromosikan penghormatan terhadap hak-hak asasi manusia sebagai ciri yang penting suatu negara hukum yang demokratis. 
Pasal 27 ayat (3) UU ITE berpotensi melanggar kebebsan berekspresi, berpendapat, dan menyebarkan informasi. Kebebasan berekspresi juga merupakan salah satu syarat penting yang memungkinkan berlangsungnya demokrasi dan partisipasi publik dalam pembuatan keputusan-keputusan. Tidak hanya penting bagi martabat individu, tetapi juga untuk berpartisipasi, pertanggungjawaban, dan demokrasi. Pelanggaran terhadap kebebasan berekspresi seringkali terjadi berbarengan dengan pelanggaran lainnya, terutama pelanggaran terhadap hak atas kebebasan untuk berserikat dan berkumpul.

Terhadap alasan para pemohon tersebut diatas, pemerintah dapat menyampaikan penjelasan atau argumentasinya, yaitu bahwa prinsip negara hukum dan kedaulatan rakyat dalam realisasinya telah menjadi norma dalam UUD 1945 sehingga prinsip-prinsip tersebut sebagai cita hukum akan dan harus tercermin dalam peraturan perundang-undangan nasional. Salah satu tujuan undang-undang yaitu sebagai barometer atau ukuran pengaturan terhadap perbuatan perbuatan yang bersumber dari konstitusi itu sendiri (hak-hak konstitusional), akan tetapi dilain pihak undang-undang juga berperan untuk melindungi hak-hak konstitusional dari pihak yang wajib mendapatkan perlindungan hukum. Dengan demikian harmonisasi dalam kehidupan bermasyarakat, berbangsa dan bernegara dapat tercipta.

\section{Pertanggungjawaban Pidana Pelaku Pencemaran Nama Baik Melalui Media} Sosial

Pencemaran nama baik pada dasarnya merupakan suatu perbuatan atau tindakan yang telah dianggap sebagai bentuk ketidakadilan sebelum dinyatakan dalm undang-undang karena telah melanggar kaidah sopan santun. Adapun beberapa catatan penting terkait dengan delik pencemaran nama baik yaitu:

1. Pertama, delik itu bersifat amat subyektif. Artinya, penilaian terhadap pencemaran nama baik amat bergantung pada orang atau pihak yang diserang nama baiknya. Karena itu, pencemaran nama baik merupakan delik aduan yang hanya bisa diproses oleh polisi jika ada pengaduan dari orang atau pidak yang merasa nama baiknya dicemarkan; 
2. Kedua, pencemaran nama baik merupakan delik penyebaran. Artinya, substansi yang berisi pencemaran disebarluaskan kepada umum atau dilakukan di depan umum oleh pelaku;

3. Ketiga, orang yang melakukan pencemaran nama baik dengan menuduh suatu hal yang dianggap menyerang nama baik seseorang atau pihak lain harus diberi kesempatan untuk membuktikan tuduhan itu.

Pada dasarnya, dalam konsep teori hukum pidana yang sering diperbincangkan yaitu tentang Tindak pidana, Pertanggungjawaban pidana dan pemidanaan. Selanjutnya yang akan dibahas yaitu tentang pertanggungjawaban pidana. Pertanggungjawaban Pidana atau yang dapat disebut (criminal responsibility) yang menjurus kepada pemidanaan terhadap pelaku yang bertujuan untuk menentukan apakah seseorang terdakwa atau tersangka dipertanggung jawabkan atas suatu tindakan pidana yang terjadi atau tidak. Seseorang dapat dijatuhkan sanksi pidana pada saat dimana seseorang tersebut melakukan perbuatan tindak pidana dan dapat diminta pertanggungjawaban pidana, kemudian baru dapat diketahui bagaimana seseorang tersebut diketahui jenis sanksi apa yang tepat, seberapa berat dan lamanya waktu pidana yang dapat dijatuhkan.

Pertanggungjawaban tindak pidana pencemaran nama baik melalui media sosial dapat diterapkan dengan sanksi pidana penjara maupun denda sesuai dengan ketentuan undang-undang yang berlaku. Pertanggungjawaban tersebut dibebankan sesuai dengan unsur pidana yang telah ditinjau dari syarat-syarat pertanggungjawaban pidana, sehingga pelaku tindak pidana pencemaran nama baik melalui media sosial dapat dipertanggungjawabkan perbuatannya seperti yang telah diputuskan dalam pengadilan.

\section{Kesimpulan}

Konstruksi hukum dan efektifitas pertanggungjawaban bagi pelaku tindak pidana pencemaran nama baik melalui media social telah diatur dalam Pasal 27 ayat (3) Undang-undang Nomor 11 Tahun 2008 tentang Informasi dan Transaksi Elektronik jo Pasal 45 ayat (3) Undang-undang Nomor 19 Tahun 2016 tentang 
Informasi dan Transaksi Elektronik. Di dalam KUHP tindak pidana pencemaran nama baik diatur dalam Pasal 310 ayat (1) KUHP.

Bahwa pebuatan pada beberapa putusan diatas dimana terdakwa mengupload pada akun facebook yang menunjukkan adanya motif atau niat untuk melakukan penghinaan dan/atau pencemaran nama baik terhadap pelaku. Dan dengan demikian perbuatan tersebut memenuhi unsur pidana dalam Pasal 45 ayat (3) UU ITE. Dalam Pasal tersebut mensyaratkan adanya unsur sengaja dalam mendistribusikan informasi elektronik yang bermuatan penghinaan dan atau pencemaran nama baik.

\section{Daftar Bacaan}

\section{Buku}

Adami Chazawi, Hukum Pidana Positifpenghinaan (Edisi Revisi) (Media Nusantara Creative 2016).

Adami.Chazawi, Hukum Pidana Positif Penghinaan PMN (Putra Media Nusantara 2009).

Adami Chazawi, Hukum Pidana Positif Penghinaan (CV. Putra Media Nusantara 2009).

Ahmad Ramli, Cyber Law dan HAKI-Dalam System Hukum Indonesia (Rafika Aditama 2004).

Amir Ilyas, Memahami Tindak Pidana Dan Pertanggungjawaban Pidana Sebagai Syarat Pemidanaan (Rangkang Education Yogyakarta \& PuKAP-Indonesia, 2012).

El Muhtaj Majda, Hak Asasi dalam Konstitusi Indonesia (Kencanai 2007).

Moeljatno, Asas-Asas Hukum Pidana (PT.Bina Aksara 1982).

Leden Marpaung, Tindak Pidana Terhadap Kehormatan (PT.Sinar Grafika 2010)

Satochid Kartanegara, Hukum Pidana II Delik-Delik Tertentu.

\section{Jurnal}

Asrianto Zainal, 'Pencemaran Nama Baik Melalui Teknologi Informasi Ditinjau Dari Hukum Pidana' (2016) 9 Fakultas Syariah IAIN Kediri. 
Reydi Vridell Awawangi, 'Pencemaran Nama Baik Dalam KUHP Dan Menurut UU No.11 Tahun 2008 Tentang Informasi Dan Transaksi Elektronik' (2014) 3 Lex Crimen.

\section{Laman}

Jupri, Delik Penghinaan, https://www.negarahukum.com/hukum/delik-penghinaan. html, Desember 2011, dikunjungi pada tanggal 25 Januari 2020. 